\title{
How to conduct a coverage exercise: A rapid assessment tool for programs and services
}

Carey Meyers

Population Council

Solene Lardoux

Follow this and additional works at: https://knowledgecommons.popcouncil.org/departments_sbsr-pgy

Part of the Demography, Population, and Ecology Commons, Family, Life Course, and Society Commons, International Public Health Commons, and the Quantitative, Qualitative, Comparative, and Historical Methodologies Commons How does access to this work benefit you? Let us know!

\section{Recommended Citation}

Meyers, Carey and Solene Lardoux. 2006. "How to conduct a coverage exercise: A rapid assessment tool for programs and services." New York: Population Council. 


\section{Q Population Council}

\section{How to Conduct a Coverage Exercise: A Rapid Assessment Tool for Programs and Services}

*How to Conduct a Coverage Exercise is also available in French, Portuguese, and Spanish.

\section{Population Council}

\section{July 2006}

Any part of this publication may be copied or adapted to meet local needs without permission from the Population Council, provided that the parts copied are distributed free or at cost (not for profit) and that the source is identified. The Population Council would appreciate receiving a copy of any materials in which the text is used.

Copyright (C) 2006 The Population Council, Inc. 


\title{
12 Population Council
}

\section{Acknowledgments:}

The original concept of a coverage exercise (CE) was presented at a Population Council/United Nations Fund for Population Activities (UNFPA) meeting on 1-3 May, 2002 in New York. A resulting paper was published entitled, "Transitions to Adulthood: Adolescent and Youth Sexual and Reproductive Health: Charting directions for a second generation of programming" (2003). The idea for a coverage exercise was laid out by Judith Bruce in chapter 2 of the paper, "Steps in Building Evidence-Based Programs for Adolescents" (available on-line at http://www.popcouncil.org/pdfs/AYSRH/2ib1.pdf).

The first coverage exercise was conducted in Ethiopia in 2003 by the Population Council (Annabel Erulkar and Tekle-Ab Mekbib) in collaboration with Private Associations Cooperating Together (PACT, USAID-funded) and 13 youth-serving organizations. The data was first presented in seminars with partner organizations in 2004, and published in 2005 (Mekbib, Erulkar, and Belete, 2005).

A coverage exercise in Burkina Faso was undertaken in the context of a partnership between UNFPA, the Population Council and 20 youth-serving organizations. Participants in the process include Geneviève Ah Sue and Siaka Traoré from UNFPA and Zio Simplice Batebié as a consultant.

Coverage exercises were conducted in Mauritania and Guinea-Bissau through a collaboration between the Population Council, UNFPA and local organizations. Participants in the Mauritania exercise include Mohamed Baraket, Seynath Aidara, Elhacen Mohamed Abdellahi, Delphine Vazeilles, Yao Gaspard Bossou from UNFPA, Bih Abdel Kader, Moctar Ould Ndiack from Direction of Youth, and Mohamed Aly Ould Ekeibed as a consultant. Participants in the GuineaBissau exercise include Guy de Araujo, Joaquim Gomes, Candida Lopes and Nélida Rodrigues from UNFPA, N'kitcha No Obna and Mauricio Sanca from Institute of Youth, and Placido Cardoso as a consultant.

The preparation of this present guide by the Population Council is supported through a collaboration with the Futures Group under USAID's Contract number HRN-C-00-00-00006-00, with additional support from the Department for International Development (DfID) (through the Population Council's adolescent girls program) and UNFPA. This guide was prepared by Carey Meyers and Solène Lardoux, who acknowledge the substantive and editorial contributions by Annabel Erulkar, Heidi Jones, Amy Joyce, Judith Bruce, Saumya RamaRao and collaborators at the Futures Group.

Any part of this guide may be copied or adapted to meet local needs without permission from the Population Council, provided that the parts copied are distributed freely or at cost (not for profit) and that the source is identified. Any commercial reproduction requires prior permission from the Population Council. The Population Council would appreciate receiving a copy of any materials in which the text is used, or of any reports in which results of coverage exercises using these tools are presented. Correspondence should be directed to:

\author{
Judith Bruce \\ Population Council \\ One Dag Hammarskjold Plaza \\ New York, NY 10017 \\ 212-339-0500 (phone) \\ jbruce@popcouncil.org \\ http://www.popcouncil.org
}




\section{Q Population Council}

\section{Table of Contents}

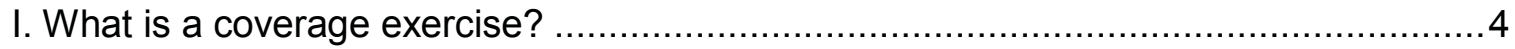

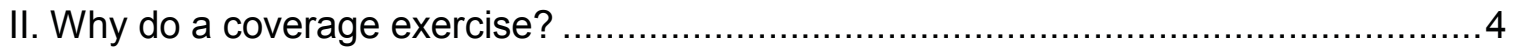

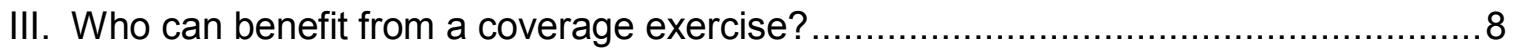

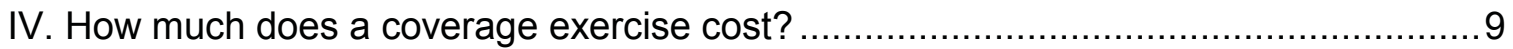

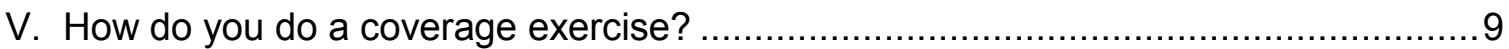

Phase 1. Selecting partners and setting a common format and framework ..................10

Phase 2. Sensitizing staff and overall planning...................................................12

Finalizing data collection tool (the activity register) .........................................14

Preparing for the training workshop ...............................................................16

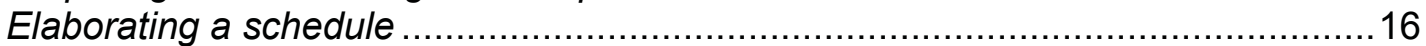

Phase 3. Conducting the training and starting data collection................................17

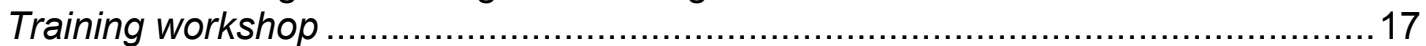

How project assistants can support peer educators or other service providers ......19

Collecting data forms ..........................................................................20

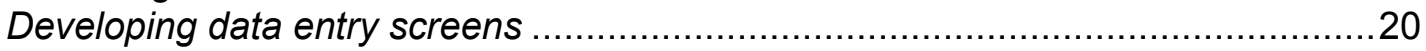

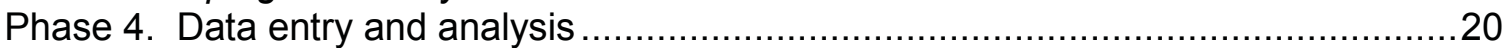

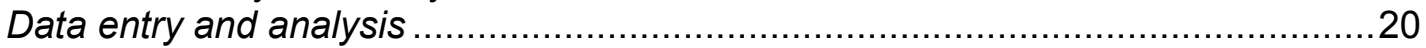

Packaging preliminary results for dissemination ...........................................2

Phase 5. Disseminating data and re-evaluating programs and policies around peer

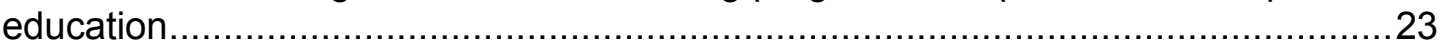

Dissemination workshop with peer educators, service providers, and program

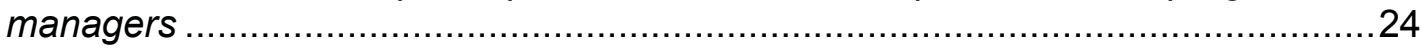

Dissemination workshop with donors, government agencies, policy makers, and other stakeholders ...........................................................................24 Revamping programs to better capture those underserved by existing models - or determining other methods for reaching those not currently participating in peer education programs.

Annex A.1: Data Collection Form Designed for Hand Tabulation ...............................26

Annex A.2 : Worksheet: Mapping Content of Adolescent Programs ............................27

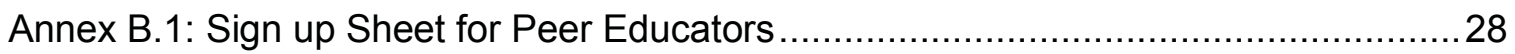

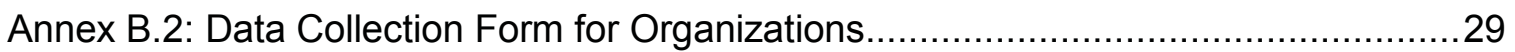

Annex B.3: Individual Activity Register for a Peer Educator or Service Provider ............ 30

Annex B.4: Sign up Sheet for Group Activities of Peer Educators ...................................31

Annex B.5: Activity Register For A Youth Center................................................... 32

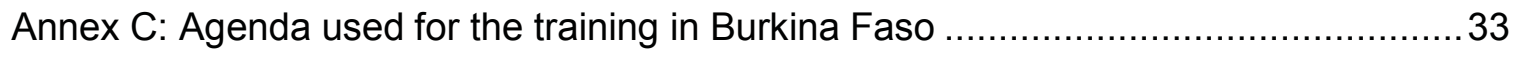

Annex D: Sample results from Mauritania coverage exercise.....................................34 


\section{What is a coverage exercise?}

A coverage exercise (CE) is a simple, low-cost, rapid assessment tool that can be used to profile who is reached by a given service or group of service providers ${ }^{1}$ or organizations with a common clientele operating within a particular geographic area. This tool was developed to assist programs servicing youth, but it can be used for other beneficiaries as well. It can be used for a range of services, both those based in a facility and those conducted on an outreach basis. A CE collects data on a variety of characteristics including gender, schooling status, living arrangements, work status, and marital status of those benefiting from a program or service. It also enables program staff and managers to take a systematic look at which services they are actually providing, where exactly they are being provided, and whether program beneficiaries are repeat customers or not. The ultimate purpose of the tool is to determine: 1 . whether services offered are reaching the intended beneficiaries and 2 . if services are appropriate for those receiving them.

A CE provides community, faith-based and non-governmental organizations, local government programs and USAID implementing partners and cooperating agencies a basic monitoring and evaluation $(\mathrm{M}+\mathrm{E})$ tool that is simple to use and low in cost. Understanding whether programs are reaching intended beneficiaries or not helps implementers and donors focus their activities and funding to reach the most at need.

\section{Why do a coverage exercise?}

Researchers at the Population Council developed the CE to offer youth-serving organizations a sustainable monitoring and evaluation tool that recognizes the diversity of adolescent populations and lives. Acknowledging that adolescents with different characteristics, such as age, gender and marital status, have different needs is sometimes overlooked, yet is essential for understanding adolescents' vulnerabilities (see box below for further detail). A 12-year old unmarried, out-of-school girl, living away from her rural home with distant "cousins" in an unfamiliar urban area as a domestic worker has markedly different needs from a 19-year old, educated, engaged girl living with both of her parents - and both have needs that differ from a 16-year old boy in a semi-rural area who has been orphaned by AIDS and is trying to attend school

\footnotetext{
${ }^{1}$ The term "service providers" refers to anyone who provides "services" such as information exchange in peer education programs or by youth center staff. It does not only refer to healthcare workers.
} 


\section{Q Population Council}

while supporting and caring for his younger siblings. National data, like those collected in the Demographic Health Surveys (DHS), can help describe proportions of adolescents in a country that fall into these different types of categories. The box below provides a detailed description, based on DHS data, of characteristics that set adolescents apart from one another. A CE illuminates which adolescents (or other populations being studied) from each of these types of categories are being reached by programs targeting them, as well as which are not.

Diversity of Adolescents: Population Council tabulations of DHS data on adolescents

The Population Council adolescent tables, "Facts About Adolescents from the Demographic and Health Survey" presents information on young people aged 10-24 on the following areas:

- Residence status (urban/rural)

- Population distribution

- $\quad$ Living arrangements

- Parental survival status and residence in household

- Characteristics of head of household

- Educational enrollment and attainment (urban/rural)

- Marital status

- Current marital status

- Married by ages $15,18,20$

- $\quad$ Adolescent schooling and work status, by marital and childbearing status

- Sexual activity and childbearing

- $\quad$ Reproductive health knowledge, behavior, and special risks

- Awareness and use of modern contraceptive methods

- $\quad$ Awareness of HIVIAIDS

- Experience with sexually transmitted infections

- $\quad$ Female genital circumcision (only collected for certain countries)

A second series of tabulations were compiled on very young adolescents (aged 10-14) in response to increased interest in learning more about this subgroup. "Selected DHS Data on 1014-year-olds" covers many of the dimensions above (residence, living arrangements, schooling) but focuses in addition on:

- Mapping girls and boys by living arrangement and school enrollment, to see what proportion are without both protective structures of parents and school

- The relationship between living arrangements and school enrollment, and how this differs by gender

- The proportion of girls who had sex, married, or gave birth before age 15

- Exposure to radio and television (urban/rural)

See http://www.popcouncil.org/gfd/gfddhs.html for further information.

Staff at the Population Council, motivated by previous assessments of the reach of youth serving organizations, have developed this tool and applied it to youth-serving programs in Ethiopia (2004), Burkina Faso (2005), Mauritania (2005) and Guinea-Bissau (2006). 
The CE allows service providers and organizers of services to see the internal diversity of those they serve, and identify the proportion of youth as broken down by subgroups: age, gender, schooling status, marital status, and living arrangements (and other relevant categories). Below are two basic charts that can be generated by organizations that collect data during a CE. These data can be used to provide commentary on whether their programs are currently reaching the populations they intend to reach.

These data can be used to profile who their programs are currently reaching, compared to who they intend to reach.

Table 1. Distribution of adolescents according to age and gender by schooling status

\begin{tabular}{|l|c|c|c|}
\hline \multirow{2}{*}{ Age and gender } & \multicolumn{2}{l}{ Schooling status } \\
\cline { 2 - 4 } & $\begin{array}{l}\text { Attending primary } \\
\text { school }\end{array}$ & $\begin{array}{l}\text { Attending } \\
\text { secondary school }\end{array}$ & Out of school \\
\hline Girls 10-14 & A & B & C \\
\hline Girls 15-19 & D & E & F \\
\hline Boys 10-14 & G & H & I \\
\hline Boys 15-19 & J & K & L \\
\hline
\end{tabular}

Table 2. Distribution of adolescents according to age and gender by marital and living situation status

\begin{tabular}{|l|l|l|l|c|}
\hline & \multicolumn{2}{|l|}{ Marital status } & \multicolumn{2}{l|}{ Living situation status } \\
\cline { 2 - 5 } $\begin{array}{l}\text { Age and } \\
\text { gender }\end{array}$ & $\begin{array}{l}\text { Married with } \\
\text { or without } \\
\text { children }\end{array}$ & $\begin{array}{l}\text { Not married } \\
\text { with or } \\
\text { without } \\
\text { children }\end{array}$ & $\begin{array}{l}\text { Living with } \\
\text { both parents }\end{array}$ & $\begin{array}{l}\text { Living with } \\
\text { one or neither } \\
\text { parent }\end{array}$ \\
\hline Girls 10-14 & A & B & A & B \\
\hline Girls 15-19 & C & D & E \\
\hline Boys 10-14 & E & F & G & F \\
\hline Boys 15-19 & G & H & H \\
\hline
\end{tabular}

Source: Adapted from table (p. 41) in "Steps in building evidence-based programs for adolescents," (Judith Bruce), Chapter 2 of Charting Directions for a Second Generation of Programming, background document for the UNFPA/Population Council workshop on Adolescent and Youth Sexual and Reproductive Health: Charting Directions for a Second Generation of Adolescent Programming, New York, 1-3 May 2002. 
With data thus generated through a CE, organizations can decide if their program objectives are being met and/or if they want to shift their approach and outreach to serve a different group of adolescents and/or offer different services to those whom they already serve.

A coverage exercise, when first implemented with an organization, provides a rapid, cross-sectional evaluation while also establishing a baseline for future monitoring. One of the CEs most notable features is that data are collected by those who have face-toface interactions with program beneficiaries. This means, for example, that a peer education program would use its peer educators to collect data. Furthermore, data are collected in the normal course of work making data collection inexpensive to conduct. All that is needed is a data collection form, also known as an activity register (see Annexes A.1, A.2, B.1, B.3, B.4, and B.5), a pen, and something to write on. Statistical analysis software can expedite the tabulation process after data collection, but data can also be tabulated manually (see Annex A.1). ${ }^{2}$

\section{Benefits of a coverage exercise:}

- Allows program managers and services providers (like peer educators or youth center staff) to know who they are and are not reaching

- Acts as both a monitoring and evaluation tool

- Builds future capacity for monitoring and evaluation of programs

- Is easy to use (does not require high literacy or sophisticated data analysis skills)

- Is low-tech and replicable

- Is low cost

- Allows for ownership of data

- Uses those who deliver services to collect data as part of normal work routine

- Provides a feedback mechanism for workers who rarely have one

\footnotetext{
2 At some point, a parallel exercise to the coverage exercise should be undertaken to inventory the content of programs offered by governments and nongovernmental organizations. Annex A.2 is an example of the sort of tool that could be used to help determine which programmatic "entry points" (health, education, work, etc.) are claiming the bulk of programmatic attention and resources. This tool will be broadly indicative, serving as a very general guide to help identify neglected subject matters and neglected subsets of youth.
} 


\section{Who can benefit from a coverage exercise?}

Many stakeholders can benefit from a coverage exercise. They include, but are not limited to:

- individual service-giving organizations

- a group or community of organizations serving a common clientele

- a group or community of organizations operating within a given catchment area (city, region, country)

- program planners

- donors

Individual organizations who want to understand who they are reaching should do a CE. For youth services, these could be peer education programs, programs that focus on a specific activity, like football or livelihoods, and/or faith-based organizations.

A community of organizations serving a common clientele who want to know who is being "picked up" by programs, versus who is left behind should also do a CE. Is one organization reaching more girls than boys? What strategies may allow this organization to reach more young people whereas others are reaching less? Common problems may be identified allowing for cross-institutional discussion and sharing.

A community of organizations within a given catchment area who want to understand differential access to services in the area should also do a CE. Which populations are being reached in the area? Are some populations not being reached at all? Is there a difference in profile of the services received by age, gender and social characteristics?

Program planners should initiate implementing a CE to help identify programmatic gaps, or to increase the reach of programs that are successfully meeting their goals.

Donors should use CEs to know how programmatic funding is being used, who is being reached through investments, and with what types of services and outreach. The results of a CE help donors identify needs and target future investments. 


\section{How much does a coverage exercise cost?}

The main expenses of a first-time coverage exercise are training workshops (including travel and per diems for participants), creating and photocopying data collection tools, human resources to manage and analyze data, and dissemination workshops.

The experience of conducting coverage exercises in four different African countries provides a basis for cost estimation. Assuming participation of between 13 and 20 organizations, local direct costs are running under US\$10,000. In Ethiopia, 6 weeks of data collection on the part of 13 major youth-serving organizations cost US\$7000. In Burkina Faso, 20 organizations collecting data over 6 weeks in both urban and rural sites cost under US\$15,000. External technical collaboration costs for the 4 sites to date have run between US\$10,000 and US\$15,000 per site. Therefore, if all direct costs are included, a coverage exercise involving 13-20 organizations can and usually does cost under US\$25,000.

If a community-based organization (CBO) were to implement a coverage exercise on its own, without hiring research help, and choosing not to share the results with others, the costs of a coverage exercise would be nominal - it would be the cost of data collection tools, and staff time to tabulate data. ${ }^{3}$

\section{How do you do a coverage exercise?}

A coverage exercise is done in 5 main phases over approximately 7 months:

1. Selecting partners and setting a common format and framework (4 weeks)

2. Sensitizing staff and overall planning (4 weeks)

3. Conducting the training and data collection (4-6 weeks)

4. Entering and analyzing data (4-6 weeks)

5. Dissemination of seminar data and initial dialogue with participating organizations, donors, and program and policy decisionmakers (1-2 days for dissemination)

\footnotetext{
${ }^{3}$ The original data collection tool (see Annex A.1) first appeared in "Steps in Building Evidence-Based Programs for Adolescents" (Bruce, 2003). It is the simplest form that an organization could use and allows for hand tabulations.
} 
Both conducting a coverage exercise at a centralized location, such as a youth centers and in an outreach program, such as a peer education program follow these same phases. Keep in mind that it is possible, and often desirable, to do both a coverage exercise of a peer education program and of a youth center at the same time. For instance, if a youth center offers a variety of activities, including peer education, then it is possible to nest a peer education coverage exercise within a larger youth center study. While one team focuses on the overall program usage of the youth center, peer educators can collect data on outreach activities. Looking at both types of activities allows for a very comprehensive understanding of the scope of services offered at a youth center, or by a youth program.

\section{Phase 1. Selecting partners and setting a common format and framework}

\section{- Estimated time: 4 weeks}

\section{- Key activities accomplished:}

- Identified organizations to implement exercise

- Collected background information on the programs/organizations being studied

The key in this step is flexibility. Partners will vary according to the policy, donor and other needs within a country or region. In some places, there are preexisting consortia of youth-serving organizations which can provide a base. For example, in Ethiopia, PACT (an umbrella organization providing technical support to a network of NGOs) collaborated with the Population Council and the Ministry of Youth. In Burkina Faso, Mauritania and Guinea Bissau, staff at UNFPA and the Population Council identified youth-service providers; a high proportion of such organizations contacted wished to participate in the information collection. In some settings, donors may have a particularly strong interest in these assessments as they wish to make evidenced based decisions about how to direct resources for young people to reach those most in need.

Upon the selection of partners and point persons, the stakeholders need to specify their goals. Any and all of the following could be selected. Do the stakeholders want to identify:

- Who a specific organization or program is reaching?

- Which subgroups a community of organizations with a common clientele are meeting? 
- Who within a geographic area and for a specific population, such as adolescents $10-14$, is being reached by all programs?

- Who is being reached by programs funded by a specific donor?

A CE can be used to define the beneficiary profile for a single program, for a cluster of programs within the same organization, for a given catchment area, across the full universe of youth-serving organizations, within a region, or project national coverage. In Mauritania, Burkina Faso and Guinea-Bissau, UNFPA was committed to having nationally-representative coverage data. Opting for national coverage means wide-scale access to a number of youth-serving institutions and results that can contribute to larger policy decisions as well as program-level shifts. Another option is to focus a CE on only one organization. For example, if a cooperating agency were considering a partnership with the largest peer education program in Yaoundé to provide health information to urban, out-of-school girls aged 15-19, it could use the CE to determine how well the program currently delivers these services.

In order to collect information on populations being reached by more than one organization, it is important for the team doing the CE to first identify the main organizations working on reaching the target population and then select a representative group of these organizations. Organizations that participate in a multi-site CE always have the option of contributing raw data to a larger effort while preserving their anonymity - analyses can be instructive without being tied to specific programs.

Once it has been determined which program or programs are participating, it is important to decide who will be collecting the data. One option is to have all of the peer educators or other service providers from the program(s) participate. Another option is to take a representative sample of the service providers participating-paying close attention to characteristics such as age, gender and schooling status. If a program has 10 peer educators and there are 5 boys and 5 girls, they may decide to have 2 of each participate. If a program had 8 girls and 2 boys, they may decide to have 4 girls and 1 boy participate. It may be that the most active peer educators or other service providers are selected to participate because of their engagement with the program. This is fine, provided that the tabulations are interpreted bearing this in mind. One of the first steps in this stage, therefore, is to collect information on the peer educators' or other service 
providers' characteristics themselves (see Annex B.1 for a sample form). Once it has been decided who will collect the data, it is important to think about timing; decide on an appropriate length of time (anywhere from 1-12 weeks) for the data collection period so that it will accurately represent the entire year.

\section{Phase 2. Sensitizing staff and overall planning}

\section{- Estimated time: 4 weeks}

- Key activities accomplished:

- engagement of participating organization(s)

- selection of team

- finalized data collection tool

- prepared for training workshop

- elaborated a timeline for the CE

The first step in phase 2 is to identify the person responsible for overall management of the CE (or the project coordinator), as well as the point-person at each participating organization or program. Establishing a common ground and understanding of project goals is essential at this point. In cases where a single organization is conducting a CE, this stage will be simplified by having a program manager, staff member, or highly motivated peer educator or service provider serve as the project coordinator.

Once the main partners agree on goals, the project coordinator should brief CBOs about the coverage exercise activity and invite them to participate. The coordinator typically explains that his or her agency is sponsoring a capacity-building activity that will yield useful information about program beneficiaries. There is no cost to the organization. All that is asked is that they send all, or a representative subgroup of, peer educators or other service providers, to a training, and that they be willing to collect data in addition to their other responsibilities for the duration of the study period (four to six weeks). One to two months after they finish collecting data, they will be invited back for another meeting where they will learn the results of the study and be asked for their feedback and input.

If a program is invited to participate and its managers decline - either because they feel their staff is too burdened or they will be judged by the CE - or for some other reason the program coordinator should consider inviting the managers to the dissemination 
workshop. This will provide them the opportunity to judge for themselves the utility of the coverage exercise.

In cases where a CBO is implementing a coverage exercise on its own, it may be desirable to train all of the current peer educators to collect information rather than just a select few. In this instance, a program manager or administrator would likely serve the coordinator role, perhaps in partnership with a technical assistance agency for the first implementation, and the CE would yield information on both the overall state of the program as well as individual-level achievements among peer educators. The result would be, in effect, a self-evaluation for each peer educator as well as the beginnings of a management information system (MIS). Once the CBO has completed a single $\mathrm{CE}$, it will be able to continue routine service data collection and analysis.

\section{Benefits to an organization of participating in a coverage exercise}

- builds capacity for both individuals and institutions

- program staff usually welcome trainings and consider them useful

- allows for self-evaluation for those who have face-to-face contact with program beneficiaries

- provides the foundation of a management information system at the program level

- allows an organization to see who it is reaching and with what services

\section{Why organizations might hesitate to participate}

- managers may feel they are being judged

- concerns that staff are already over-stretched

The coordinator should contact participating agencies a few days prior to the workshop to confirm that the peer educators or service providers plan to attend.

At the same time, the team should identify:

- One analysis coordinator who knows how to use statistical software; in cases where only one organization is participating in the CE, the analysis coordinator should know how to generate simple cross-tabulations, either using statistical packages or manually, to conduct data analyses. Estimated time of total work: one month 
- One project assistant for every five participating organizations. Ideally, assistants are fluent in the languages spoken in the data collection areas. (Optional, but desirable.) Estimated time of total work: three weeks

- Two to three data entry assistants to perform data entry and cleaning (can be the analysis coordinator as well). Estimated time of total work: three to five weeks, depending on the amount of data expected

- One trainer to conduct the training workshop - ideally, this is the same person as the project assistant. Estimated time of total work: Three days (two days preparation, one day of workshop)

When CEs are implemented by a technical assistance agency, they provide an analysis coordinator, project assistants, and data entry as part of their support. In instances where CBOs undertake a CE on their own, existing staff may be used or it may be necessary to hire consultants to fulfill some of these roles.

Youth centers may require additional staff, as they are typically buildings with common space both indoors and outdoors. Popular youth centers may attract hundreds of adolescents per day. At the same time, youth centers tend to have few staff members. There may be a youth center manager, and then just enough additional staff (sometimes paid, sometimes voluntary) to provide an adult presence amidst all of the young people. This combination of factors makes it slightly more challenging for youth center staff to collect data compared to peer educators. One way to optimize the number of youth center attendees who are logged in a data register is to place a staff member at the exit of the center. That person can then add people to the register as they leave the center each time during the study period. This may not be practical, however, because there are often so few staff at a youth center. Another approach, therefore, is to hire one or two project assistants per youth center to sit at an exit and record young people as they leave the facility. Depending on which approach is used, the planning phase may require hiring and training project assistants. It is the people who have been designated as the data collectors who should attend the training workshop.

\section{Finalizing data collection tool (the activity register)}

Once the research team is in place, it is time to prepare for the training workshop. An essential step is working on the data collection forms (the activity registers) in consultation with peer educators, other service providers, their managers, or 


\section{Population Council}

both. For those seeking the quickest and simplest form of this tool, please refer to Annex A.1. This simpler form lends itself to hand calculations and is more comparable to a time in/time out register. To begin the data collection process, we provide a form to collect information on the peer educators themselves (Annex B.1) and a questionnaire for the organizations to complete at the outset (Annex B.2). In Annex B.3, we provide a sample activity register for peer educators to use for their one-on-one activities (based on the one used in the Ethiopia CE), while Annex B.4 shows an example of a group activity register for peer educators to use for their group activities (also based on the Ethiopia CE). In Annex B.5, we provide a sample activity register to be used at the entrance or exit of a youth center (based on the one used in Mauritania). In some instances, it will be useful to have a pre-workshop meeting, perhaps a week or even a day before the training, to discuss the data collection form and make adjustments to take into account the local context. It will be important to consider the timing (with respect to school vacation, holidays, special events, etc.) and length (duration of time) of the data collection period. Depending on the context, funding, and assessment of variation over the time period, the duration of data collection may vary (ranging from 1-12 weeks). If you are trying to capture a snapshot of services offered, you may only want to collect the data for 1-2 weeks; if you are trying to get a full comprehensive picture, it might be useful to collect the information for a longer period of time in order to collect accurate information.

Though the basic elements of the form will remain constant from one setting to another, it is important to make sure that terms are relevant locally. For example, the category for marital status may need to change depending on the context; terms such as 'cohabitation' or 'long-term relationship' rather than 'single' or 'married' may better reflect the social context in some settings. It is essential that the forms reflect peer educators' and other service providers' actual scope of work. In addition to the simple activity registers, the forms designed to collect information on the peer educators (Annex B.1) and the organizations themselves (Annex B.2) will provide useful contextual information. Make sure the peer educator fills in her/his name and the organization she/he works for so that the data collectors can link the appropriate peer educators to the correct organizations and to their activity registers. Remember, you will want to see if boys talk to boys, if girls talk to girls, and so forth. 


\section{Population Council}

\section{Preparing for the training workshop}

The agenda used for the training in Burkina Faso is attached (see Annex C). In addition to developing an agenda, gathering research supplies and duplicating the activity registers are important. After the workshop, peer educators and other service providers will return to their communities ready to collect data. This means that they will leave the workshop with everything they need to do so. This includes:

- Sufficient data collection forms to last throughout the study period. In Burkina Faso, each peer educator was given enough forms to record up to 300 contacts. This was an ample supply. In other contexts, it might not be enough. Peer educators will not necessarily know how many beneficiaries they come into contact with in the course of a month (one of the reasons to do a CE is to learn exactly this), thus a balance must be struck between giving peer educators a data collection kit that is not too heavy and burdensome and one that will last them through the data collection period. In Burkina Faso, each peer was given 60 activity registers for individual information (Annex B.3) and 20 activity registers for group activities (Annex B.4). When project assistants made field visits, they brought extra forms with them to replenish supplies as needed.

- Pens with which to complete the forms.

- Complementary materials (a list of codes if not on the forms themselves, a list of contact information for the team).

- $\quad$ Binders to secure these materials and make them easy to transport.

\section{Elaborating a schedule}

The team should develop a time line for the coverage exercise, beginning with the training and following through Phase 3 (see below).

The team should also decide how they will collect the data collection forms at the end of the coverage exercise. Peer educators and other service providers may have traveled from remote rural areas to a nation's capital for training, but it is probably unrealistic in terms of both time and expense to have them come back at the end of the collection period to hand their forms to the program manager. Where possible, it is certainly ideal to have peer educators turn in their completed activity registers in person, or have one peer educator from each region collect the registers for the group in his/her region and travel to return the forms. Where it is not possible, other options should be discussed 
prior to fielding the CE. In some contexts, it may be practical or efficient for one project assistant to travel from site to site collecting forms. Some places have informal messenger systems - this worked well in Burkina Faso. In the end, local partners will have the best sense of how to transport data in an efficient and safe manner from rural areas to central levels.

\section{Phase 3. Conducting the training and starting data collection}

\section{- Estimated time: 4-6 weeks (could be longer if data collection period is up to 12 weeks)} - Key activities accomplished:

- trained peer educators or other service providers to collect information about their activities and those with whom they come in contact

- project assistants in place to support data collection

- collection of completed forms

- development of data entry screens

\section{Training workshop}

The training workshop requires one day (in places with limited access, it may be necessary to plan for an additional day as participants could spend a day traveling to get to the workshop). Typically, the coordinator introduces the rationale for the CE, and then the trainer teaches participating peer educators or other service providers how to use the data collection form. The trainer explains, column by column, what to fill in and different options for posing questions during field work. The trainer reviews confidentiality guidelines (it is not necessary to record the name of any person) and the purpose of the program assessment, including how the data will be used. There is ample time for questions and answers and interaction between trainer and trainees. After an initial explanation, peer educators or other service providers role play with the form to practice collecting information. The trainer and project assistants circulate the room to work with small groups and individuals, making sure that everyone understands how to use the form and how to pose questions. Once they have mastered these skills (allow up to an hour for this), a second form is introduced: it captures the same information, and is designed to make data collection easier in large groups. Again, the trainer explains how to complete the form, then the peer educators or other service providers practice doing so with each other. The trainer emphasizes the following points: 


\section{(1) Population Council}

- Complete the form for each and every person with whom you interact in your role as peer educator or service provider, even if that person is older or younger than your target age group and even if the encounter is in a group situation.

- It is not necessary to record the name of the person - all data collected is confidential.

- If someone does not want to be recorded in the activity register, they do not have to be. But it is required to write NA at the start of the row and go to the next row for the next contact.

- In the list of activities, it is essential to list all that apply to a particular exchange multiple responses are fine; the same is true for topics covered. (This requires extra practice during the role play.)

- Activity registers should always be completed in pen.

- The register is designed to note repeat customers; they should record interactions with the same people, even if they talk to the same people every day. This information is very valuable!

- They should not plan special activities during the data collection period - they should conduct business as usual.

- They alone should add names to the register; if they are conducting a group session, they may have an assistant circulate the venue to complete the group activity log.

- They should carry their activity register folders with them everywhere for the duration of the study period.

- They should ask the questions after he/she had an exchange with the peer. The series of questions is short and should not take more than two minutes to answer. At the training, it is important to insist on the fact that this activity should not disturb their role of peer educator or other service provider. And this activity of filling the questionnaire should not affect the quality of the present and future relationships with the peer.

- During the training, it is helpful to remind the peer educators that this exercise is valuable for them because it allows them to keep track of all exchanges they have had during the month. It is like taking a picture of what is actually happening, what they do in reality and is a unique opportunity for them to let others know what their work consists of.

- Throughout the workshop, the trainer should allow time for questions and comments about the forms in order to make sure that everyone understands the exercise as well as to foster participation and sharing of comments. For instance, some peer educators may be wondering about the understanding of a question by the peer. The trainer should explain all of the questions and the possible 


\section{Population Council}

answers to each of them. Before the end of the training workshop, the trainer should make sure that there are no outstanding questions, and that the trainees have mastered how to fill out the form, before they go on to the field.

- The trainer should provide a sentence of introduction in the CE instruction guide for the peer educators or other service providers so that they can explain briefly the purpose of asking some questions to the peer. They will then read the sentence before they fill the activity register in front of the peer. This is an example of the sentence: "Do you mind if I ask you a few questions? I am reporting all the contacts I have with peers in order for the association to know better about my work. Peer educators are doing it all over the country this month. You don't need to give your name."

Peer educators or other service providers depart the workshop with all of the materials and information they need, including contact information for the project assistants (if there are any involved). They are instructed to begin data collection as soon as they return to their home and resume activities, and to call the project coordinator if they have any questions at all. In some settings, if the CE budget permits, it may be desirable to provide the peer educators with a phone card.

\section{How project assistants can support peer educators or other service providers}

A word about project assistants, and how to decide whether to have them: The role of project assistants during the data collection phase is to provide support to the peer educators or other service providers collecting data. They do so by making themselves available through phone and/or in-person contact. This helps peer educators handle different situations that they encounter in the field or helps if they run out of forms. Project assistants are not necessary but do contribute to quality data. If program managers have attended the training workshop, they can offer support to peer educators in lieu of project assistants. Depending on the context, a centralized system of support may not be necessary. For instance, if an entire organization has its peer educators participating in a CE, then they can act as reinforcements to each other. They would have built-in contact with a manager and with a study team.

When project assistants are engaged, they may carry out their work by phoning the peer educators regularly and/or visiting each peer educator at least once during the data collection period, traveling by bus, train, or bush taxi, and staying in simple guest 
houses. Multiple sites are combined in one trip, so a project assistant may spend two weeks in the field going from site to site.

\section{Collecting data forms}

At the end of the designated data collection period, activity registers should be sent though whichever method agreed upon - to the project coordinator.

\section{Developing data entry screens}

During the data collection period, the analysis coordinator will prepare a data entry screen to facilitate later entry. A program like Epi Info can be used. He or she will also oversee retrieval of the data collection forms from field sites and manage the forms when they arrive. This includes making a record of each form that comes in from the field, and creating a code that anonymously ties a set of forms to a particular peer educator and/or organization. At this time, the coordinator trains data entry staff on entry using the screen.

\section{Phase 4. Data entry and analysis}

\section{- Estimated time: 4-6 weeks}

- Key activities accomplished:

- data is entered into computer software and analyzed, or tabulated manually and analyzed

- preliminary results are generated and packaged for discussion

\section{Data entry and analysis}

The analysis coordinator will oversee data entry and data cleaning. This means either using Epi Info or another statistical software package, or tabulating columns manually. Alternatively, a CBO can elect one of its staff, or a small team of staff, to compile the results of the $\mathrm{CE}$. The choice to take one approach or another depends on the capacity of the institution implementing the CE. Annex $D$ includes a series of tables and figures 


\section{Population Council}

that have been generated from previous coverage exercises. The completed forms should be stored in a safe place until the analyses are completed and the data checked and verified (up to one year).

The analysis should:

- Always stratify by gender, and usually also by age. One approach is to use DHS age groupings (10-14, 15-19), or to use smaller age groups such as 10-12, 1315 , and 16-19.

- Consult the disaggregated DHS tables, or similar, if they are available for the country. (See the Council's website, http://www.popcouncil.org/gfd/gfddhs. html, for a list of countries and further information, if more recent data or additional analyses are desired for a particular country, or to request an analysis for a country that is not already included).

- Analyze by organization, by type of organization (i.e. organizations funded by a particular donor), and by location (urban/rural) of activity

- Analyze by marital status.

- Analyze by schooling status.

- Analyze by characteristics of the peer educator or other service provider. Answer the questions, "Do female peer educators tend to talk more to females? Do male peer educators tend to talk more to males? What are the ages of the peer educators compared to those with whom they speak?"

- Answer the following questions:

- "How many subjects do peer educators talk about in the typical exchange?"

- "What is the topic, or the combination of several topics, that comes up the most often in exchanges with peer educators? How does it vary by the gender of the peer and the peer educator?"

- "What are the socio-demographic characteristics of the peers that are reached by the peer educators (gender, age, highest level of schooling, marital status, living arrangement, working status)?"

- "Where does the exchange take place (at the youth center, clinic, school, in the fields, at the market, on the soccer/basketball field, in a community association or another location that should be specified)?"

- "If the exchange happens during an activity, what is the nature of this activity (large/small group discussion, individual discussion, question and answer, sports, drama, video show, referrals, pill distribution, condom distribution, counseling, medical treatment)?"

Examples of tables and figures that can be generated are found in Annex D. 


\section{Some results from the Ethiopia coverage exercise}

The Ethiopia coverage exercise was conducted over a six week period with 13 of the largest youth-serving organizations in the country. Results include:

- Programs reached more males than females, with nearly 60 percent of contacts being boys or men.

- Older boys and men dominated the programs, with 45 percent of contacts being boys aged 15 and older, and 1 out of 5 being men aged 20 or older. Fourteen percent of contacts were over the desired age of 24 .

- Programs were reaching the more advantaged in-school population while most Ethiopian adolescents are out of school.

- Information about HIVIAIDS was the most frequent service rendered -reaching 73 percent of the boys and 64 percent of the girls. The content of this message may require further analysis, as only 15 percent of girls and 7 percent of boys received information about gender roles, and only 23 percent of the boys (who tended to be older) received information about condoms.

- Only three percent of female contacts were married even though the majority of girls in Ethiopia marry during adolescence and most sexually active girls are married.

Source: Mekbib, Erulkar, and Belete, 2005.

Available on-line at:

http://www.cih.uib.no/journals/EJHD/ejhd19-no1/60.Who\%20are\%20the\%20targets\%20of\%20youth\%20programs.pdf

It is notable that, in the Ethiopia example above, there is a significant skewing of resources, directed at school-going, older youth, often males, and also that the profile of services at youth centers is becoming reoriented to focus primarily on HIVIAIDS while many other kinds of information (life skills, gender, relationship issues) appear not to be getting much attention. This is also apparent in the data from Burkina Faso which reports that the majority of information received by contacts was about HIVIAIDS (21 percent of boys and 16 percent of girls) while other subjects received much less attention, including life skills information being received by only 5 percent of boys and 3 percent of girls (Population Council and UNFPA, 2005). 


\section{Packaging preliminary results for dissemination}

Once the analysis is complete, the project coordinator should draft a readily understandable report and ideally an accompanying, visually appealing presentation that will be shared with peer educators or other service providers and program managers, and later with other stakeholders.

The presentation should be used as a starting point for analysis, to engage program managers and implementers into the process of thinking about their beneficiaries. This presentation should attempt to compare and contrast nationally-representative DHS data with the results from the CE. For instance, disaggregated DHS data in a particular setting may show that 78 percent of 15-19 year old girls are not in school. The CE shows that among 15-19 year old girls using a CBO's service, 78 percent are in school. This comparison would help a CBO draw the conclusion that they are reaching a small and special proportion of 15-19 year old girls, since the majority of girls are not in school but the majority of their program participants are in school. The results must also be presented in the context of the target population(s) of the program(s).

During this phase, the project coordinator should proceed to organize a dissemination workshop with program managers and peer educators.

\section{Phase 5. Disseminating data and re-evaluating programs and policies around peer education}

\section{Estimated time: 1-2 days for (each) dissemination; program and policy shift will be} ongoing

- Key activities accomplished:

- dissemination workshop with peer educators, service providers, and program managers

- dissemination workshop with donors, government agencies, and policy makers

- revamping programs to better capture those underserved by existing models - or determining other methods for reaching those not currently participating in programs 
Dissemination workshop with peer educators, service providers, and program managers

Peer educators - and other service providers who collected the data - and their managers are the first groups to see the analyses. Data from both the DHS and the CE should be presented in a clear and simple manner that is understandable to the group so that they may interpret them for themselves. A facilitator may guide discussion of what the data reflect and what additional analyses are warranted and requested by organizations. Discussions of why results are as they are and strategies for improving program performance and increasing coverage should be discussed. This is also a good time for program staff to discuss institutionalizing the CE. They will now be familiar with the current situation of their program coverage, and can decide the best way to institutionalize its use for managing and monitoring their future work.

Dissemination workshop with donors, government agencies, policy makers, and other stakeholders

Drawing on the responses and recommendations of peer educators and managers, a presentation can be designed to share at a second dissemination meeting. This meeting will include donors and policy makers and is an opportunity to propose new ways of reaching out to underserved groups as well as reporting on existing program deficiencies. Importantly, participating groups will share what they learned in the process and steps they are taking to improve their coverage and outreach to the underserved.

Revamping programs to better capture those underserved by existing models - or determining other methods for reaching those not currently participating in peer education programs

Results from the coverage exercise and discussions at the dissemination workshops may be used to bolster or shift existing models - or help inspire ideas for new ones. Immediately following the coverage exercise is a good time to explore changes. Ideas are still fresh and motivation may still be high. 


\section{(2) Population Council}

This present guideline provides information as well as illustrative tools and results from previous coverage exercises. Experience to date suggests that service providers at all levels - within community organizations, non-governmental organizations, local government programs, and USAID implementing partners - can use this simple tool to monitor and evaluate their programs. The outcome of data collection helps service providers and program managers understand whether their programs are reaching intended beneficiaries or not which in turn helps implementers and donors focus their activities and funding to reach underserved audiences as defined by both level of vulnerability and numerical weight. 
Annex A.1: Data Collection Form Designed for Hand Tabulation

\begin{tabular}{|c|c|c|c|c|c|c|c|c|}
\hline & $\begin{array}{c}\text { Number of } \\
\text { adolescents in each } \\
\text { category seen in the } \\
\text { last } 30 \text { days }\end{array}$ & $\begin{array}{c}\# \text { of } \\
\text { 10-14-year-olds }\end{array}$ & $\begin{array}{c}\# \text { of } \\
\text { 15-19-year-olds }\end{array}$ & \# of girls & \# of boys & $\begin{array}{c}\text { \# of adolescents in } \\
\text { school }\end{array}$ & $\begin{array}{c}\text { \# of adolescents } \\
\text { out of school }\end{array}$ & $\begin{array}{c}\text { \# of married } \\
\text { adolescents }\end{array}$ \\
\hline \multicolumn{9}{|l|}{ Girls } \\
\hline $\begin{array}{l}\text { 1. Unmarried girls } \\
\text { aged } 10-14, \\
\text { in school }\end{array}$ & $\mathbf{A}$ & $\mathbf{A}$ & & $\mathbf{A}$ & & $\mathbf{A}$ & & \\
\hline $\begin{array}{l}\text { 2. Unmarried girls } \\
\text { aged } 10-14, \\
\text { out of school }\end{array}$ & B & B & & B & & & B & \\
\hline $\begin{array}{l}\text { 3. Unmarried girls } \\
\text { aged } 15-19, \\
\text { in school }\end{array}$ & $\mathbf{C}$ & & $\mathbf{C}$ & $\mathbf{C}$ & & $\mathbf{C}$ & & \\
\hline $\begin{array}{l}\text { 4. Unmarried girls } \\
\text { aged } 15-19 \text {, } \\
\text { out of school }\end{array}$ & D & & D & D & & & D & \\
\hline $\begin{array}{l}\text { 5. Married girls* } \\
\text { aged } 10-14\end{array}$ & $\mathbf{E}$ & $\mathbf{E}$ & & $\mathbf{E}$ & & & $\mathbf{E}$ & $\mathbf{E}$ \\
\hline $\begin{array}{l}\text { 6. Married girls* } \\
\text { aged } 15-19\end{array}$ & $\mathbf{F}$ & & $\mathbf{F}$ & $\mathbf{F}$ & & & $\mathbf{F}$ & $\mathbf{F}$ \\
\hline \multicolumn{9}{|l|}{ Boys } \\
\hline $\begin{array}{l}\text { 7. Unmarried boys } \\
\text { aged } 10-14, \\
\text { in school }\end{array}$ & $\mathbf{G}$ & $\mathbf{G}$ & & & $\mathbf{G}$ & $\mathbf{G}$ & & \\
\hline $\begin{array}{l}\text { 8. Unmarried boys } \\
\text { aged } 10-14, \\
\text { out of school }\end{array}$ & $\mathbf{H}$ & $\mathbf{H}$ & & & $\mathbf{H}$ & & $\mathbf{H}$ & \\
\hline $\begin{array}{l}\text { 9. Unmarried boys } \\
\text { aged } 15-19, \\
\text { in school }\end{array}$ & $\mathbf{I}$ & & I & & $\mathbf{I}$ & $\mathbf{I}$ & & \\
\hline $\begin{array}{l}\text { 10. Unmarried boys } \\
\text { aged } 15-19, \\
\text { out of school }\end{array}$ & $\mathbf{J}$ & & $\mathbf{J}$ & & $\mathbf{J}$ & & $\mathbf{J}$ & \\
\hline $\begin{array}{l}\text { 11. Married boys } \\
\text { aged } 15-19^{* *}\end{array}$ & $\mathbf{K}$ & & $\mathbf{K}$ & & $\mathbf{K}$ & & & $\mathbf{K}$ \\
\hline Total: & $\begin{array}{c}\mathbf{A}+\mathbf{B}+\mathbf{C}+\mathbf{D}+\mathbf{E}+\mathbf{F}+\mathbf{G} \\
+\mathbf{H}+\mathbf{I}+\mathbf{J}+\mathbf{K}\end{array}$ & $\mathbf{A}+\mathbf{B}+\mathbf{E}+\mathbf{G}+\mathbf{H}$ & $\mathbf{C}+\mathbf{D}+\mathbf{F}+\mathbf{I}+\mathbf{J}+\mathbf{K}$ & $\begin{array}{c}\mathbf{A}+\mathbf{B}+\mathbf{C}+\mathbf{D}+ \\
\mathbf{E}+\mathbf{F} \\
\end{array}$ & $\begin{array}{c}\mathbf{G}+\mathbf{H}+\mathbf{I}+\mathbf{J}+ \\
\mathbf{K} \\
\end{array}$ & $\mathbf{A}+\mathbf{C}+\mathbf{G}+\mathbf{I}$ & $\begin{array}{c}\mathbf{B}+\mathbf{D}+\mathbf{E}+\mathbf{F}+\mathbf{H}+ \\
\mathbf{J}\end{array}$ & $\mathbf{E}+\mathbf{F}+\mathbf{K}$ \\
\hline
\end{tabular}

*Married adolescent girls are rarely found in school; therefore, their schooling status is not indicated.

**Boys ages 10-14 are rarely married; therefore, they are not included on this worksheet.

This tool was originally drafted to get people interested; it was first implemented by service providers in low-income areas of New York City (in 1973). At that time, tabulation was done by hand by service-providing staff. As excerpted from Judith Bruce's chapter 2, "Steps in building evidence-based programs for adolescents," this simple tool can "[g]ather and analyze data on adolescents — grouped by age, gender, marital and schooling status, residence, and other relevant variables - through careful situation analyses and other research methodologies" (2003; p. 29). 
Annex A.2 Worksheet: Mapping Content of Adolescent Programs

\begin{tabular}{|c|c|c|c|c|c|c|c|}
\hline $\begin{array}{l}\text { Program Content } \\
\text { Categories }\end{array}$ & $\begin{array}{l}\text { Age group } \\
\text { served }\end{array}$ & Gender* & $\begin{array}{l}\text { Schooling } \\
\text { status }^{\Delta}\end{array}$ & $\begin{array}{l}\text { Activities } \\
\text { reaching } \\
\text { married } \\
\text { adolescents }\end{array}$ & $\begin{array}{c}\text { Numbers } \\
\text { served annually }\end{array}$ & $\begin{array}{c}\% \text { of overall } \\
\text { program effort } \\
-20,40,60 \\
80,100 \% \\
\end{array}$ & $\begin{array}{l}\text { Key entry } \\
\text { point? }\end{array}$ \\
\hline \multicolumn{8}{|l|}{$\begin{array}{l}\text { Functional literacy and } \\
\text { out of school learning }\end{array}$} \\
\hline \multicolumn{8}{|l|}{ Nutrition } \\
\hline \multicolumn{8}{|l|}{$\begin{array}{l}\text { Reproductive health } \\
\text { information }\end{array}$} \\
\hline \multicolumn{8}{|l|}{ Health services } \\
\hline \multicolumn{8}{|l|}{$\begin{array}{l}\text { Livelihoods and skills } \\
\text { training }\end{array}$} \\
\hline \multicolumn{8}{|l|}{$\begin{array}{l}\text { Savings opportunities/ } \\
\text { economic literacy }\end{array}$} \\
\hline \multicolumn{8}{|l|}{$\begin{array}{l}\text { Offering } \\
\text { protection/security to } \\
\text { vulnerable adolescents }\end{array}$} \\
\hline \multicolumn{8}{|l|}{$\begin{array}{l}\text { Fostering adolescent } \\
\text { participation in } \\
\text { community and civic } \\
\text { processes }\end{array}$} \\
\hline \multicolumn{8}{|l|}{$\begin{array}{l}\text { Offering opportunities to } \\
\text { increase physical } \\
\text { strength/ } \\
\text { sport and gaming skills }\end{array}$} \\
\hline \multicolumn{8}{|l|}{$\begin{array}{l}\text { Establishing non-school, } \\
\text { non-family } \\
\text { learning/developmental } \\
\text { spaces for young people }\end{array}$} \\
\hline $\begin{array}{l}\text { * Solely or majority girls - } \\
\text { Solely or majority boys - } \\
\text { More or less equallv mix }\end{array}$ & & & $\begin{array}{l}\text { Most parti } \\
\text { Most parti } \\
\text { More or le }\end{array}$ & $\begin{array}{l}\text { its in school } \\
\text { nts out of sch } \\
\text { qually mixed }\end{array}$ & $\mathrm{M}$ & & \\
\hline
\end{tabular}

Note: This worksheet and the program areas listed are illustrative only. In a given setting, these categories should be specified to reflect the context. 
12 Population Council

Annex B.1: Sign up Sheet for Peer Educators*

\begin{tabular}{|c|c|c|c|c|c|c|c|c|c|c|}
\hline \begin{tabular}{|l|} 
(1) \\
Peer \\
Educator \\
ID\#
\end{tabular} & $\begin{array}{l}\text { (2) } \\
\text { Name }\end{array}$ & \begin{tabular}{|c|}
$(3)$ \\
Organization
\end{tabular} & $\begin{array}{c}\text { (4) } \\
\text { How } \\
\text { old are } \\
\text { you? }\end{array}$ & $\begin{array}{l}\text { (5) } \\
\text { Are } \\
\text { you a } \\
\text { girl or } \\
\text { a boy? }\end{array}$ & $\begin{array}{c}\text { (6) } \\
\text { Are you } \\
\text { currently } \\
\text { enrolled } \\
\text { in } \\
\text { school? } \\
\text { (Yes/No) }\end{array}$ & $\begin{array}{c}\text { (7) } \\
\text { What is the } \\
\text { highest level } \\
\text { of education } \\
\text { you have } \\
\text { completed? }\end{array}$ & $\begin{array}{c}(8) \\
\text { Do you live with } \\
\text { both parents, } \\
\text { mother only, } \\
\text { father only, other } \\
\text { relatives, } \\
\text { spouse, non } \\
\text { relatives, or } \\
\text { alone? }\end{array}$ & $\begin{array}{c}9) \\
\text { Are you } \\
\text { married, } \\
\text { never } \\
\text { married, } \\
\text { separated, } \\
\text { divorced or } \\
\text { widowed? }\end{array}$ & $\begin{array}{c}(10) \\
\text { How long } \\
\text { have you } \\
\text { been a } \\
\text { peer } \\
\text { educator? }\end{array}$ & $\begin{array}{c}\text { (11) } \\
\text { What were you } \\
\text { trained in? } \\
\text { Use codes. } \\
\text { Report all topics } \\
\text { cited } \\
\text { (multiple choices) }\end{array}$ \\
\hline 1 & Amy & $\begin{array}{l}\text { Population } \\
\text { Council }\end{array}$ & 24 & Girl & No & Grade 9 & Both parents & $\begin{array}{l}\text { Never } \\
\text { married }\end{array}$ & 3 months. & $1,3,8$ \\
\hline 2 & & & & & & & & & & \\
\hline 3 & & & & & & & & & & \\
\hline 4 & & & & & & & & & & \\
\hline 5 & & & & & & & & & & \\
\hline 6 & & & & & & & & & & \\
\hline 7 & & & & & & & & & & \\
\hline 8 & & & & & & & & & & \\
\hline 9 & & & & & & & & & & \\
\hline 10 & & & & & & & & & & \\
\hline 11 & & & & & & & & & & \\
\hline 12 & & & & & & & & & & \\
\hline 13 & & & & & & & & & & \\
\hline 14 & & & & & & & & & & \\
\hline 15 & & & & & & & & & & \\
\hline
\end{tabular}

* This form is for the peer educators to fill out.

\begin{tabular}{|l|l|l|}
\hline TOPIC CODES: & 7= CONDOMS & $13=$ DELINQUENCY \\
1= HIVIAIDS & 8= EMERGENCY CONTRACEPTION & $14=$ GENDER ISSUES \\
2=FAMILY PLANNING & $9=$ HYGIENE/SANITATION & $15=$ CHILD TRAFFICKING \\
3=STIS & 10= LIFE SKILLS & $16=$ MARRIAGE \\
4= PREGNANCY & $11=$ FAMILY AND SOCIAL & $17=$ CHILD RIGHTS \\
$5=$ ABORTION & ISSUES/RELATIONSHIPS & $18=$ OTHER (PLEASE SPECIFY IN TABLE) \\
$6=$ FGC & 12=DRUGS/ALCOHOL & \\
& & \\
& & \\
\hline
\end{tabular}




\section{Annex B.2: Data Collection Form for Organizations.}

1. Organization name:

2. Address:

3. Which cities/regions do you work in?

$\begin{array}{ccc}\text { Urban } & \text { Rural } & \text { Both } \\ \square & \square & \square \\ \square & \square & \square\end{array}$

4. How many peer educators worked for you in 2005 ?

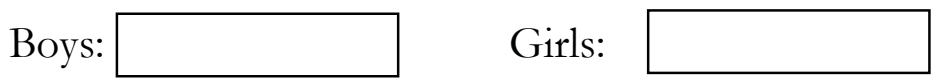

5. What is the target population for your peer education program? Do you reach particular subgroups (in-school/out-of-school, younger/older)?

6. What topics have your peer educators been trained in? (Please mark all that apply.)

$\begin{array}{lll}\square \text { HIV/AIDS } & \square \text { STIs } & \square \text { HYGIENE/SANITATION } \\ \square \text { LIFE SKILLS } & \square \text { CONDOMS } & \square \text { FAMILY PLANNING } \\ \square \text { GENDER } & \square \text { PREGNANCY } & \square \text { EMERGENCY CONTRACEPTION } \\ \square \text { ABORTION } & \square \text { DRUGS/ALCOHOL } & \square \text { FEMALE GENITAL CUTTING } \\ \square \text { MARRIAGE } & \square \text { DELINQUENCY } & \square \text { CHILD TRAFFICKING } \\ \square \text { FAMILY AND } & \square \text { CHILD RIGHTS } \\ \text { SOCIAL ISSUES/ } & \square \text { OTHER (PLEASE SPECIFY) } \\ \text { RELATIONSHIPS } & \\ \text { What activities are peer educators involved in? } & \\ \square \text { INDIVIDUAL DISCUSSION } & \square \text { GROUP DISCUSSION } \\ \square \text { INFORMATION-GIVING } & \square \text { DRAMA/THEATRE } \\ \square \text { CONDOM DISTRIBUTION } & \square \text { REFERRALS TO CLINIC SERVICES }\end{array}$


(2) Population Council

(1) Name of Service Provider / Peer Educator

Annex B.3: Individual Activity Register for a Peer Educator or Service Provider

\section{Record each person contacted on one line.}

\begin{tabular}{|c|c|c|c|c|c|c|c|c|c|c|c|c|c|}
\hline $\begin{array}{c}\text { (3) } \\
\text { Date }\end{array}$ & $\begin{array}{l}(4) \\
\text { Sex }\end{array}$ & $\begin{array}{c}\text { (5) } \\
\text { First } \\
\text { contact } \\
\text { with the } \\
\text { program? }\end{array}$ & $\begin{array}{c}6) \\
\text { Recorded } \\
\text { in } \\
\text { register } \\
\text { before? }\end{array}$ & $\begin{array}{c}(7) \\
\text { Individual } \\
\text { or group } \\
\text { contact? }\end{array}$ & $\begin{array}{c}\text { (8) } \\
\text { Location of } \\
\text { contact } \\
\text { (Use codes } \\
\text { More than one } \\
\text { code allowed.) } \\
\end{array}$ & $\begin{array}{c}\text { (9) } \\
\text { Type of services } \\
\text { (Use codes. } \\
\text { More than one } \\
\text { code allowed) }\end{array}$ & $\begin{array}{c}(10) \\
\text { Topics Covered } \\
\text { (Use codes. } \\
\text { More than one } \\
\text { code allowed) }\end{array}$ & $\begin{array}{c}\text { (11) } \\
\text { Are you } \\
\text { currently } \\
\text { enrolled in } \\
\text { school? }\end{array}$ & $\begin{array}{c}(11) \\
\text { Highest level of } \\
\text { schooling }\end{array}$ & $\begin{array}{l}\text { (12) } \\
\text { Worked for } \\
\text { pay in the last } \\
\text { month? }\end{array}$ & $\begin{array}{c}\text { (13) } \\
\text { Who do you live } \\
\text { with? } \\
\text { (Use codes) }\end{array}$ & $\begin{array}{c}\text { (14) } \\
\text { Marital Status } \\
\text { (Use codes) }\end{array}$ & $\begin{array}{l}\text { (15) } \\
\text { Age }\end{array}$ \\
\hline & $\begin{array}{l}1=\mathrm{M} \\
2=\mathrm{F}\end{array}$ & $\begin{array}{l}1=Y E S \\
2=N O\end{array}$ & $\begin{array}{l}1=Y E S \\
2=N O\end{array}$ & $\begin{array}{l}1=\text { INDIVID } \\
2=\text { GROUP }\end{array}$ & & & & $\begin{array}{l}1=Y E S \\
2=N O\end{array}$ & $\begin{array}{l}\text { 1. NONE } \\
\text { 2. PRIMARY } \\
\text { 3. SECONDARY } \\
\text { 4. KORANIC SCHOOL }\end{array}$ & $\begin{array}{l}1=Y E S \\
2=N O\end{array}$ & & & \\
\hline & $\begin{array}{l}1=M \\
2=F\end{array}$ & $\begin{array}{l}1=Y E S \\
2=N O\end{array}$ & $\begin{array}{l}1=Y E S \\
2=N O\end{array}$ & $\begin{array}{l}1=\text { INDIVID } \\
2=\text { GROUP }\end{array}$ & & & & $\begin{array}{l}1=\mathrm{YES} \\
2=\mathrm{NO}\end{array}$ & $\begin{array}{l}\text { 1. NONE } \\
\text { 2. PRIMARY } \\
\text { 3. SECONDARY } \\
\text { 4. KORANIC SCHOOL }\end{array}$ & $\begin{array}{l}1=\mathrm{YES} \\
2=\mathrm{NO}\end{array}$ & & & \\
\hline & $\begin{array}{l}1=\mathrm{M} \\
2=\mathrm{F}\end{array}$ & $\begin{array}{l}1=Y E S \\
2=N O\end{array}$ & $\begin{array}{l}1=Y E S \\
2=N O\end{array}$ & $\begin{array}{l}1=\text { INDIVID } \\
2=\text { GROUP }\end{array}$ & & & & $\begin{array}{l}1=\mathrm{YES} \\
2=\mathrm{NO}\end{array}$ & $\begin{array}{l}\text { 1. NONE } \\
\text { 2. PRIMARY } \\
\text { 3. SECONDARY } \\
\text { 4. KORANIC SCHOOL }\end{array}$ & $\begin{array}{l}1=Y E S \\
2=N O\end{array}$ & & & \\
\hline & $\begin{array}{l}1=\mathrm{M} \\
2=F\end{array}$ & $\begin{array}{l}1=Y E S \\
2=N O\end{array}$ & $\begin{array}{l}1=Y E S \\
2=N O\end{array}$ & $\begin{array}{l}1=\text { INDIVID } \\
2=\text { GROUP }\end{array}$ & & & & $\begin{array}{l}1=Y E S \\
2=N O\end{array}$ & $\begin{array}{l}\text { 1. NONE } \\
\text { 2. PRIMARY } \\
\text { 3. SECONDARY } \\
\text { 4. KORANIC SCHOOL }\end{array}$ & $\begin{array}{l}1=\mathrm{YES} \\
2=\mathrm{NO}\end{array}$ & & & \\
\hline & $\begin{array}{l}1=M \\
2=F\end{array}$ & $\begin{array}{l}1=\mathrm{YES} \\
2=\mathrm{NO}\end{array}$ & $\begin{array}{l}1=Y E S \\
2=N O\end{array}$ & $\begin{array}{l}1=\text { INDIVID } \\
2=\text { GROUP }\end{array}$ & & & & $\begin{array}{l}1=\mathrm{YES} \\
2=\mathrm{NO}\end{array}$ & $\begin{array}{l}\text { 1. NONE } \\
\text { 2. PRIMARY } \\
\text { 3. SECONDARY } \\
\text { 4. KORANIC SCHOOL }\end{array}$ & $\begin{array}{l}1=\mathrm{YES} \\
2=\mathrm{NO}\end{array}$ & & & \\
\hline
\end{tabular}

\begin{tabular}{|c|c|c|c|c|c|}
\hline $\begin{array}{l}\text { LOCATION CODES } \\
\text { 1=CENTER } \\
2=\text { CLINIC } \\
\text { 3=SCHOOL } \\
\text { 4=NEIGHBORHOOD } \\
\text { 5=MY HOUSE } \\
6=\text { YOUTH'S HOUSE } \\
\text { 7=MARKET PLACE } \\
\text { 8=COFFEE CEREMONY } \\
\text { 9=STADIUM } \\
\text { 10=COMMUNITY ASSOC. } \\
11=\text { OTHER (SPECIFY IN TABLE) }\end{array}$ & $\begin{array}{l}\text { TYPE OF SERVICE CODES: } \\
\text { 1= LECTURE } \\
\text { 2=SMALL GROUP DISCUSSION } \\
\text { 3=ONE ON ONE DISCUSSION } \\
\text { 4= QUESTION \& ANSWER } \\
\text { 5= DRAMA } \\
6=\text { VIDEO SHOW } \\
\text { 7= SPORTS } \\
\text { 8= CONDOMS PROVIDED } \\
\text { 9= PILL DISTRIBUTION } \\
\text { 10= COUNSELING } \\
\text { 11=REFERRALS } \\
\text { 12=MEDICAL TREATMENT } \\
\text { 13=OTHER (SPECIFY IN TABLE) }\end{array}$ & $\begin{array}{l}\text { TOPIC CODES: } \\
\text { 1= HIVIAIDS } \\
\text { 2=FAMILY PLANNING } \\
\text { 3=STIS } \\
\text { 4= PREGNANCY } \\
\text { 5= ABORTION } \\
\text { 6= FGC } \\
\text { 7= CONDOMS } \\
\text { 8= EMERGENCY CONTRACEPTION } \\
\text { 9= HYGIENE/SANITATION } \\
\text { 10= LIFE SKILLS }\end{array}$ & $\begin{array}{l}11=\text { FAMILY AND SOCIAL } \\
\text { ISSUES/RELATIONSHIPS } \\
12=\text { DRUGS/ALCOHOL } \\
\text { 13=DELINQUENCY } \\
\text { 14=GENDER ISSUES } \\
15=\text { CHILD TRAFFICKING } \\
16=\text { MARRIAGE } \\
\text { 17=CHILD RIGHTS } \\
\text { 18=OTHER (PLEASE SPECIFY IN } \\
\text { TABLE) }\end{array}$ & $\begin{array}{l}\text { LIVING ARRANGEMENT CODES: } \\
\text { 1=BOTH PARENTS } \\
\text { 2=MOTHER ONLY } \\
\text { 3=FATHER ONLY } \\
\text { 4=OTHER RELATIVES } \\
\text { 5= HUSBAND/WIFE } \\
\text { 6=NON RELATIVES } \\
\text { 7=ALONE }\end{array}$ & $\begin{array}{l}\text { MARITAL STATUS CODES: } \\
\text { 1=NEVER MARRIED } \\
\text { 2=MARRIED } \\
\text { 3=SEPARATED } \\
\text { 4=DIVORCED } \\
\text { 5=WIDOWED }\end{array}$ \\
\hline
\end{tabular}




\section{Annex B.4: Sign up Sheet for Group Activities of Peer Educators*}

(1) Name

( 2 ) Organization

\section{( 3 ) Peer Educator ID \#}

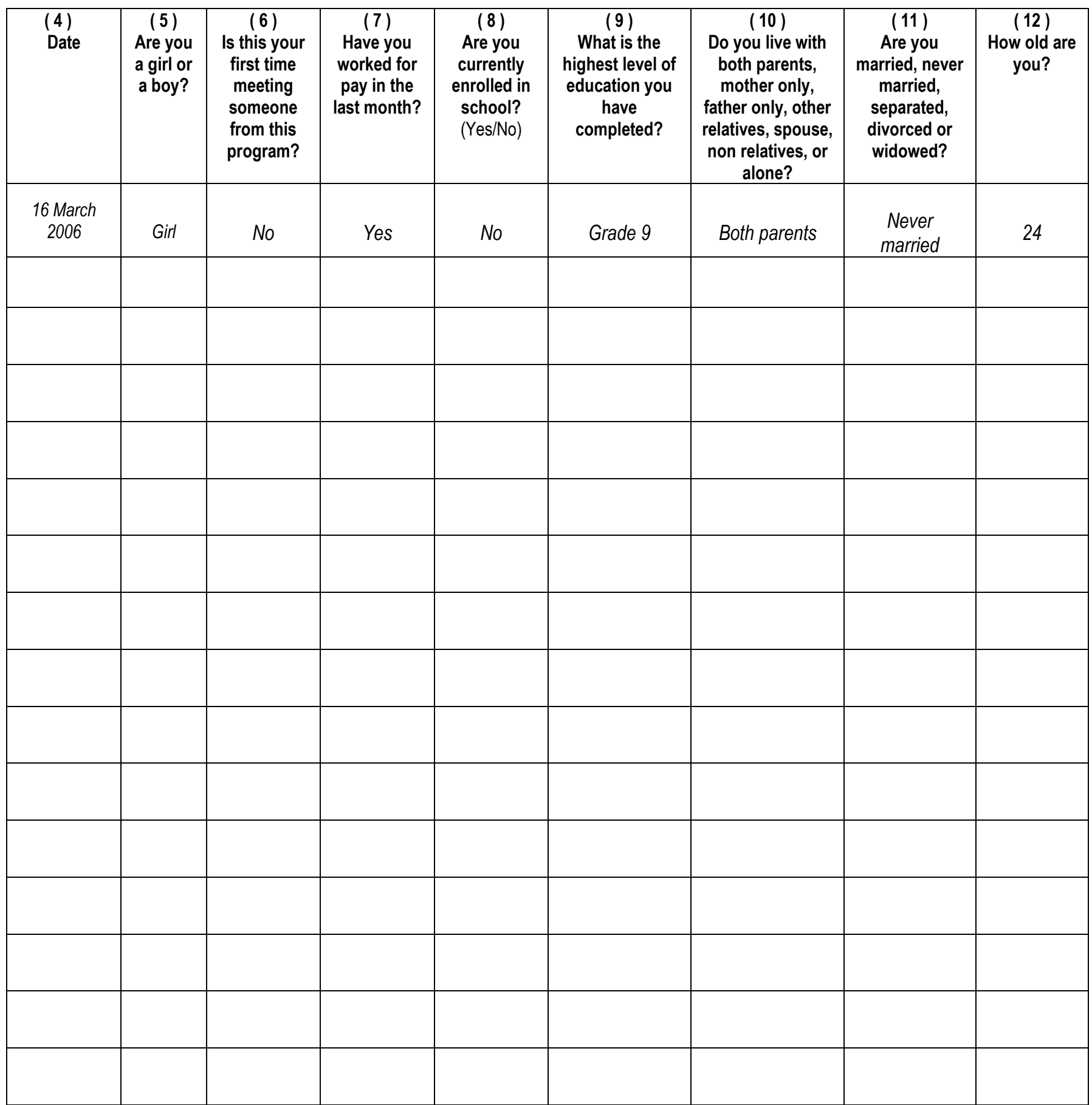

* This form is to be used when a peer educator convenes a group. 
Annex B.5 Activity Register For A Youth Center

(1) Name of Youth Center

Record each person contacted on one line.

\begin{tabular}{|c|c|c|c|c|c|c|c|c|c|c|c|c|}
\hline $\begin{array}{l}(2) \\
\text { Date }\end{array}$ & $\begin{array}{l}(3) \\
\text { Sex }\end{array}$ & $\begin{array}{c}\text { ( } 4 \text { ) } \\
\text { Activities at the } \\
\text { center } \\
\text { Use codes. } \\
\text { Report all } \\
\text { activities cited } \\
\text { (multiple choices) }\end{array}$ & $\begin{array}{c}(5) \\
\text { Participated in } \\
\text { a discussion } \\
\text { with a friend, a } \\
\text { peer educator } \\
\text { or the } \\
\text { director? }\end{array}$ & $\begin{array}{c}(6) \\
\text { Topics discussed } \\
\text { today } \\
\text { Use codes. } \\
\text { Report all topics } \\
\text { cited } \\
\text { (multiple choices) }\end{array}$ & $\begin{array}{c}\text { (7) } \\
\text { Already } \\
\text { answered the } \\
\text { questionnaire? }\end{array}$ & $\begin{array}{l}\text { ( } 8 \text { ) } \\
\text { Frequency of } \\
\text { visit at center }\end{array}$ & $\begin{array}{l}(9) \\
\text { Are you } \\
\text { currently } \\
\text { enrolled } \\
\text { in } \\
\text { school? }\end{array}$ & $\begin{array}{c}\text { (10) } \\
\text { Highest } \\
\text { level of } \\
\text { schooling }\end{array}$ & $\begin{array}{c}\text { (11) } \\
\text { Who do you live } \\
\text { with? }\end{array}$ & $\begin{array}{c}(12) \\
\text { Worked } \\
\text { for pay } \\
\text { in last } \\
\text { month? }\end{array}$ & $\begin{array}{c}(13) \\
\text { Marital status }\end{array}$ & $\begin{array}{c}(14) \\
\text { Age }\end{array}$ \\
\hline & $\begin{array}{l}\text { 1. Boy } \\
\text { 2. Girl }\end{array}$ & & $\begin{array}{l}\text { 1. No } \\
\text { (go to [6]) } \\
\text { 2. Yes } \\
\text { (continue) }\end{array}$ & & $\begin{array}{l}\text { 1. No (continue to } \\
\text { the next column } \\
\text { 2. Yes (END: If Yes, } \\
\text { pass questionnaire } \\
\text { to the next person) }\end{array}$ & $\begin{array}{l}\text { 1. Once } \\
\text { 2. 2-3 times } \\
\text { 3. 3-4 times } \\
\text { 4. every day } \\
\text { 5. less than once } \\
\text { a week but more } \\
\text { than once a } \\
\text { month }\end{array}$ & $\begin{array}{l}\text { 1. Yes } \\
\text { 2. No }\end{array}$ & $\begin{array}{l}\text { 1. None } \\
\text { 2. Primary } \\
\text { 3. Secondary } \\
\text { 4. Koranic } \\
\text { school }\end{array}$ & $\begin{array}{l}1=\text { Both parents } \\
2=\text { Mother only } \\
3=\text { Father only } \\
4=\text { Other relatives } \\
5=\text { Husband/wife } \\
6=\text { Non relatives } \\
7=\text { Alone }\end{array}$ & $\begin{array}{l}\text { 1. Yes } \\
\text { 2. No }\end{array}$ & $\begin{array}{l}\text { 1=NEVER } \\
\text { MARRIED } \\
\text { 2=MARRIED } \\
\text { 3=SEPARATED } \\
\text { 4=DIVORCED } \\
\text { 5=WIDOWED }\end{array}$ & \\
\hline & $\begin{array}{l}\text { 1. Boy } \\
\text { 2. Girl }\end{array}$ & & $\begin{array}{l}\text { 1. No } \\
\text { (go to [6]) } \\
\text { 2. Yes } \\
\text { (continue) }\end{array}$ & & $\begin{array}{l}\text { 1. No (continue to } \\
\text { the next column } \\
\text { 2. Yes (END: If Yes, } \\
\text { pass questionnaire } \\
\text { to the next person) }\end{array}$ & $\begin{array}{l}\text { 1. Once } \\
\text { 2. 2-3 times } \\
\text { 3. 3-4 times } \\
\text { 4. every day } \\
\text { 5. less than once } \\
\text { a week but more } \\
\text { than once a } \\
\text { month }\end{array}$ & $\begin{array}{l}\text { 1. Yes } \\
\text { 2. No }\end{array}$ & $\begin{array}{l}\text { 1. None } \\
\text { 2. Primary } \\
\text { 3. Secondary } \\
\text { 4. Koranic } \\
\text { school }\end{array}$ & $\begin{array}{l}1=\text { Both parents } \\
2=\text { Mother only } \\
3=\text { Father only } \\
4=\text { Other relatives } \\
5=\text { Husband/wife } \\
6=\text { Non relatives } \\
7=\text { Alone }\end{array}$ & $\begin{array}{l}\text { 1. Yes } \\
\text { 2. No }\end{array}$ & $\begin{array}{l}\text { 1=NEVER } \\
\text { MARRIED } \\
\text { 2=MARRIED } \\
\text { 3=SEPARATED } \\
\text { 4=DIVORCED } \\
\text { 5=WIDOWED }\end{array}$ & \\
\hline & $\begin{array}{l}\text { 1. Boy } \\
\text { 2. Girl }\end{array}$ & & $\begin{array}{l}\text { 1. No } \\
\text { (go to [6]) } \\
\text { 2. Yes } \\
\text { (continue) }\end{array}$ & & $\begin{array}{l}\text { 1. No (continue to } \\
\text { the next column } \\
\text { 2. Yes (END: If Yes, } \\
\text { pass questionnaire } \\
\text { to the next person) }\end{array}$ & $\begin{array}{l}\text { 1. Once } \\
\text { 2. 2-3 times } \\
\text { 3. 3-4 times } \\
\text { 4. every day } \\
\text { 5. less than once } \\
\text { a week but more } \\
\text { than once a } \\
\text { month } \\
\end{array}$ & $\begin{array}{l}\text { 1. Yes } \\
\text { 2. No }\end{array}$ & $\begin{array}{l}\text { 1. None } \\
\text { 2. Primary } \\
\text { 3. Secondary } \\
\text { 4. Koranic } \\
\text { school }\end{array}$ & $\begin{array}{l}1=\text { Both parents } \\
2=\text { Mother only } \\
3=\text { Father only } \\
4=\text { Other relatives } \\
5=\text { Husband/wife } \\
6=\text { Non relatives } \\
7=\text { Alone }\end{array}$ & $\begin{array}{l}\text { 1. Yes } \\
\text { 2. No }\end{array}$ & $\begin{array}{l}\text { 1=NEVER } \\
\text { MARRIED } \\
\text { 2=MARRIED } \\
\text { 3=SEPARATED } \\
\text { 4=DIVORCED } \\
\text { 5=WIDOWED }\end{array}$ & \\
\hline & $\begin{array}{l}\text { 1. Boy } \\
\text { 2. Girl }\end{array}$ & & $\begin{array}{l}\text { 1. No } \\
\text { (go to [6]) } \\
\text { 2. Yes } \\
\text { (continue) }\end{array}$ & & $\begin{array}{l}\text { 1. No (continue to } \\
\text { the next column } \\
\text { 2. Yes (END: If Yes, } \\
\text { pass questionnaire } \\
\text { to the next person)) }\end{array}$ & $\begin{array}{l}\text { 1. Once } \\
\text { 2. 2-3 times } \\
\text { 3. } 3-4 \text { times } \\
\text { 4. every day } \\
\text { 5. less than once } \\
\text { a week but more } \\
\text { than once a } \\
\text { month }\end{array}$ & $\begin{array}{l}\text { 1. Yes } \\
\text { 2. No }\end{array}$ & $\begin{array}{l}\text { 1. None } \\
\text { 2. Primary } \\
\text { 3. Secondary } \\
\text { 4. Koranic } \\
\text { school }\end{array}$ & $\begin{array}{l}1=\text { Both parents } \\
2=\text { Mother only } \\
3=\text { Father only } \\
4=\text { Other relatives } \\
5=\text { Husband/wife } \\
6=\text { Non relatives } \\
7=\text { Alone }\end{array}$ & $\begin{array}{l}\text { 1. Yes } \\
\text { 2. No }\end{array}$ & $\begin{array}{l}\text { 1=NEVER } \\
\text { MARRIED } \\
\text { 2=MARRIED } \\
\text { 3=SEPARATED } \\
\text { 4=DIVORCED } \\
\text { 5=WIDOWED }\end{array}$ & \\
\hline
\end{tabular}

\begin{tabular}{|l|l|l|}
\hline ACTIVITIES AT THE CENTER & 5=SCOUT MEETING & TOPIC CODES: \\
\hline CODES: & 6=THEATER & 1= HIVIAIDS \\
1=KARATE & 7=VIDEO PROJECT & 2=FAMILY PLANNING \\
2=FOOTBALL & 8=GAMES & 3=STIS \\
3=BASKETBALL & 9=DEBATE/DISCUSSION GROUP & 4= PREGNANCY \\
4=COMPUTERS & 10=OTHER (PLEASE SPECIFY IN TABLE) & 5= ABORTION \\
& & \\
\hline
\end{tabular}

6= FGC
7= CONDOMS
8= EMERGENCY CONTRACEPTION
9= HYGIENE/SANITATION
10= LIFE SKILLS

11= FAMILY AND SOCIAL ISSUES /RELATIONSHIPS 12=DRUGS/ALCOHOL

13=DELINQUENCY 14=GENDER ISSUES
15=CHILD TRAFFICKING 16=MARRIAGE 17=CHILD RIGHTS 18=OTHER (PLEASE SPECIFY IN TABLE) 


\section{Annex C: Agenda used for the training in Burkina Faso \\ Who do youth-serving organizations reach? \\ Planning a coverage exercise activity}

08:00 - 08:30

08:30 - 09:00

09:00 - 09:15

09:15 - 09:30

09:30 - 10:15

$10: 15-10: 30$

10:30 - 11:00

$11: 00-11: 15$

$11: 15-12: 30$

$12: 30-13: 15$

$13: 15-14: 00$

14:00 - 15:00

15:00 - 16:30

$16: 30-17: 00$
Registration

Welcome and introduction of presentations

Objectives of the workshop

Adolescents in Burkina Faso: some facts

Presentation of the activity register

Short demonstration by 2 participants of how to use it - role play

Break

Role play using the activity registers (all participants)

Presentation of the group register

Role play using the group register (all participants)

Lunch

Discussion and questions about the role plays (all participants; $1-2$ facilitators)

Further questions and distribution of notebooks/binders (all participants; $1-2$ facilitators)

Additional questions and discussion

Closing remarks, administrative questions 
Annex D: Sample results from Mauritania coverage exercise

(Source for tables and figures: UNPFA and Population Council, Coverage Exercise Mauritania, 2006)

Table 1. Sex ratios of those served at the five most active youth centers during data collection (data was collected for a period of one week at each youth center)

\begin{tabular}{|cccc|}
\hline Youth center & \multicolumn{3}{c|}{ Gender } \\
\cline { 2 - 3 } & Male (\%) & Female (\%) & Number \\
\hline A & 90 & 10 & 541 \\
B & 90 & 10 & 403 \\
C & 97 & 3 & 557 \\
D & 51 & 49 & 385 \\
E & 79 & 21 & 419 \\
\hline Total & $\mathbf{8 3}$ & $\mathbf{1 7}$ & $\mathbf{2 , 3 0 5}$ \\
\hline
\end{tabular}

As seen in Table 1, for all except for one of the youth centers, many more males visited the centers than females.

Table 2: Percentage distribution of individuals who came to the youth centers during data collection by age and gender (all youth centers combined)

\begin{tabular}{|l|c|c|c|c|c|c|c|l|}
\hline \multirow{2}{*}{ All youth centers } & \multicolumn{9}{|l|}{ Age group (\%) } & Number \\
\cline { 2 - 9 } & $<10$ & $10-14$ & $\mathbf{1 5 - 1 9}$ & $20-24$ & $25-29$ & $30-34$ & $35+$ & \\
\hline Male & 4 & 28 & $\mathbf{4 2}$ & 15 & 5 & 2 & 3 & 4508 \\
\hline Female & 4 & 28 & $\mathbf{4 5}$ & 15 & 5 & 2 & 1 & 944 \\
\hline Total & 4 & 28 & $\mathbf{4 2}$ & 15 & 5 & 2 & 3 & 5452 \\
\hline
\end{tabular}

As seen in Table 2, adolescents aged 15-19 comprise almost half of all of those served at youth centers. 
Table 3: Percentage distribution of individuals who came to the youth center by gender, frequency of visits per week (all youth centers)

\begin{tabular}{|l|c|c|c|c|}
\hline \multirow{2}{*}{$\begin{array}{c}\text { Number of visits } \\
\text { per week }\end{array}$} & \multicolumn{2}{|c|}{ Gender } & \multirow{2}{*}{ Total } & Number \\
\cline { 2 - 3 } & Male & Female & & \\
\hline Once & $\mathbf{1 0}$ & $\mathbf{2 4}$ & $\mathbf{1 3}$ & $\mathbf{7 0 0}$ \\
2 to 3 times & 27 & 32 & 28 & 1534 \\
4 to 5 times & 17 & 15 & 17 & 922 \\
Every day & $\mathbf{4 0}$ & $\mathbf{2 4}$ & $\mathbf{3 7}$ & $\mathbf{2 0 0 1}$ \\
Less than once & 6 & 5 & 5 & 295 \\
\hline Total & 100 & 100 & 100 & 5452 \\
\hline
\end{tabular}

As seen in Table 3, a significant proportion of users are not just repeat users but go every day - this pattern is especially true for boys, while more girls than boys visit the centers only once a week.

Table 4: Percentage distribution of individuals by level of schooling and age (all youth centers)

\begin{tabular}{|ccccccc|}
\hline \multirow{2}{*}{ Age } & \multicolumn{7}{c|}{ Level of schooling } \\
\cline { 2 - 7 } & None & Primary & Secondary & Koranic & Total & Number \\
\hline$<10$ years & 0.6 & 87.0 & $\mathbf{1 . 3}$ & 6.1 & 100 & 231 \\
$10-14$ & 0.9 & 75.0 & $\mathbf{2 2 . 5}$ & 1.6 & 100 & 1541 \\
$15-19$ & 1.2 & 15.1 & $\mathbf{8 1 . 0}$ & 2.7 & 100 & 2299 \\
$20-24$ & 3.2 & 24.3 & $\mathbf{6 8 . 6}$ & 3.8 & 100 & 832 \\
$25-29$ & 9.9 & 26.9 & $\mathbf{5 8 . 0}$ & 5.3 & 100 & 283 \\
$30-34$ & 9.3 & 23.3 & $\mathbf{6 5 . 9}$ & 1.6 & 100 & 129 \\
35 or more & 6.6 & 15.3 & $\mathbf{7 4 . 5}$ & 3.6 & 100 & 137 \\
\hline Total & 2.4 & 37.3 & $\mathbf{5 7 . 5}$ & 2.8 & 100 & 5452 \\
\hline
\end{tabular}

As seen in Table 4, note that more half of all youth encountered during this survey were in secondary school even though only 16.8 percent of girls aged 15-19 had ever attended primary school-a figure that drops to 9.3 percent for women aged 20-24 (according to 1998/1999 DHS survey data). 
Table 5: Distribution of individuals and contacts by gender and intervention zone (the donor's intervention zone)

\begin{tabular}{|lccc|}
\hline $\begin{array}{l}\text { Had an exchange with a } \\
\text { resource person or a friend } \\
\begin{array}{l}\text { at the youth centre } \\
\text { (\% in column) }\end{array}\end{array}$ & \multicolumn{2}{l}{ Gender of contact } & Total \\
\cline { 2 - 3 } & Boys & Girls & $\begin{array}{c}\% \\
(\mathrm{~N})\end{array}$ \\
\hline $\begin{array}{l}\text { Within zone of intervention } \\
\text { Yes }\end{array}$ & 36 & 60 & 41 \\
No & 64 & 40 & 59 \\
Total & 100 & 100 & 100 \\
& $(2035)$ & $(500)$ & $(2535)$ \\
\hline Out of zone of intervention & & & \\
Yes & 29 & 63 & 34 \\
No & 71 & 37 & 66 \\
Total & 100 & 100 & 100 \\
& $(4773)$ & $(807)$ & $(5580)$ \\
\hline
\end{tabular}

Figure 1. Proportion of male contacts characterized by an exchange with a resource person or a friend at the youth centre, by age group

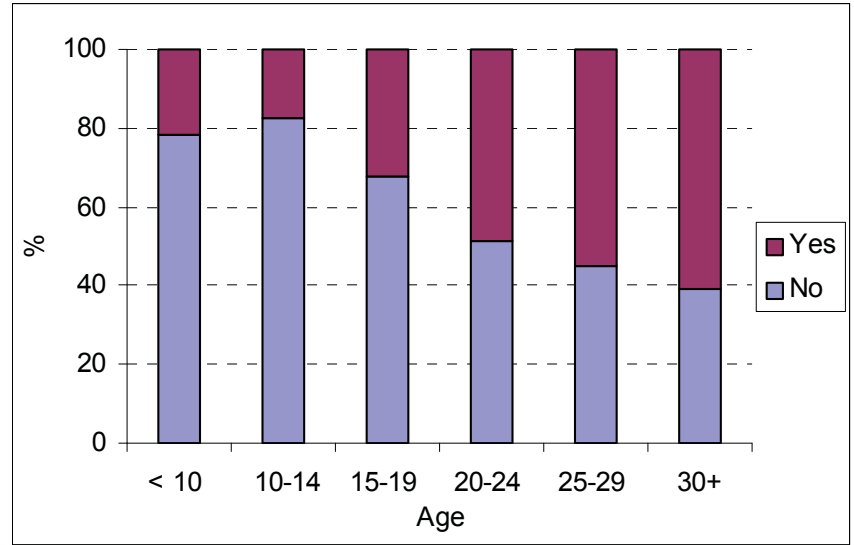


Figure 2. Proportion of female contacts characterized by an exchange with a resource person or a friend at the youth centre, by age group

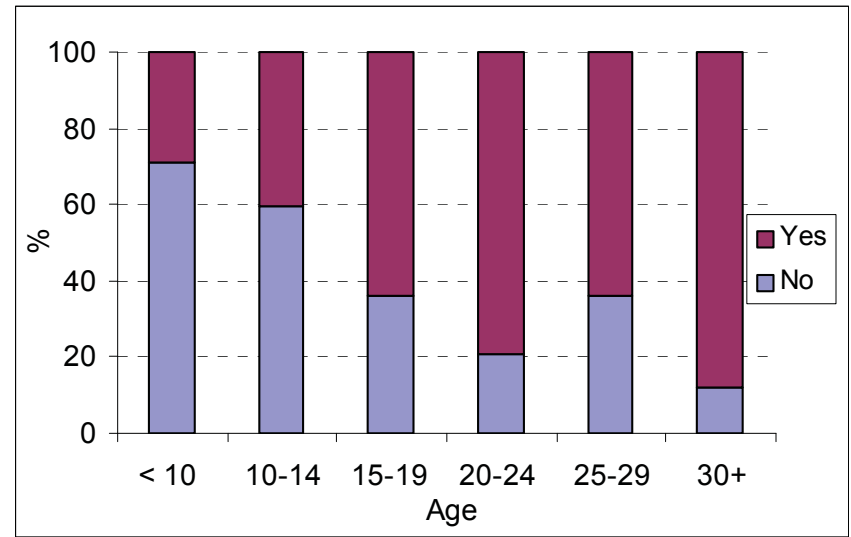




\section{References}

Bruce, Judith. 2003. "Steps in building evidence-based programs for adolescents" in "Transitions to Adulthood: Adolescent and Youth Sexual and Reproductive Health: Charting directions for a second generation of programming." Background document for the UNFPA/Population Council workshop on Adolescent and Youth Sexual and Reproductive Health: Charting Directions for a Second Generation of Adolescent Programming, New York, 13 May 2002.

Demographic and Health Survey. 1999. "Facts about adolescents from the Demographic and Health Survey—Statistical tables for program planning: Burkina Faso 1998-1999." New York, NY: Population Council.

Mekbib T, Erulkar A, Belete F. 2005. "Who are the targets of youth programs: Results of a capacity building exercise in Ethiopia." Ethiopian Journal of Health Development, Vol. 19(1): 60 -62. Available on-line at:

http://www.cih.uib.no/journals/EJHD/eihd19-no1/60.Who\%20are\%20the\%20targets\%20of\%20youth\%20programs.pdf

Population Council and UNFPA. 2005. "Exercice de couverture sur les activités des pairs éducateurs au Burkina Faso". See acknowledgments for full list of participants.

Population Council and UNFPA. 2006. "Exercice de couverture sur les activités et la fréquentation des centres de jeunes en Mauritanie." See acknowledgments for full list of participants.

Population Council and UNFPA. 2006. "Exercice de couverture sur les activités des pairs éducateurs en Guinée-Bissau." See acknowledgments for full list of participants.

"Who is being reached by youth programmes? Results from youth-serving organizations' tracking exercise." 2002. Draft presentation. Population Council, PACT Ethiopia, DSW, and Family Guidance Associate of Ethiopia. 